\title{
Living under lockdown in the shadow of the COVID-19 pandemic in South Africa: anxious voices from the unplanned shift to online therapy
}

\author{
Zelda Gillian Knight
}

Department of Psychology, Faculty of Humanities, Auckland Park Campus, University of Johannesburg, Johannesburg, South Africa

\begin{abstract}
This paper is a narrative, phenomenological description of the themes of experiences of some of my South African patients that collectively elicit anxious voices from the unplanned shift to online therapy while living under the world's longest lockdown in the shadow of the coronavirus 2019 (COVID-19) pandemic. This paper thus presents a thematic description of moments in therapy, which illustrate the influence of lockdown on their sense of self, and the emergence of new anxieties not encountered before. Such themes are: i) new anxieties about death and dying; ii) new anxieties about loss of contact with friends and family and the emergence of existential anxiety; iii) new anxieties about current household relationships and the emergence of object loss; iv) new anxieties about the unplanned shift to online therapy and the threat of internet dis-connection, and finally; v) new anxieties about missing body parts of online therapy: Part-body-on-the-screen relating versus what-was-once-whole-body relating. As this paper is based on psychoanalytic theory, and the notion of intersubjectivity, my own experiences and thoughts are included in the therapeutic engagement. The core contribution of this paper is that it adds a voice to the other voices of other patients around the world who are also living under lockdown. Without this kind of narrative documentation, the world-wide therapeutic community may not know the extent of the anxieties of living under lockdown in the shadow of the COVID-19 pandemic.
\end{abstract}

Key words: Lockdown; South Africa; online psychotherapy; anxiety; COVID-19.

\section{Introduction}

Many of my patients who live in Johannesburg, where I practice as a psychoanalytic psychotherapist, found ways to cope with living under lockdown in the shadow of the coronavirus 2019 (COVID-19) pandemic. In the early days of living under lockdown, restricted to the home, ex-

Correspondence: Zelda Gillian Knight, Department of Psychology, Faculty of Humanities, Auckland Park Campus, University of Johannesburg, Johannesburg, South Africa.

Tel.: +27.83.311.3229.

E-mail: zknight@uj.ac.za

Citation: Knight, Z. G. (2020). Living under lockdown in the shadow of the COVID-19 pandemic in South Africa: anxious voices from the unplanned shift to online therapy. Research in Psychotherapy: Psychopathology, Process and Outcome, 23(3), 202-210. doi: 10.4081/ripppo.2020.487

Received for publication: 4 August 2020.

Revision received: 2 October 2020.

Accepted for publication: 13 October 2020.

This work is licensed under a Creative Commons Attribution NonCommercial 4.0 License (CC BY-NC 4.0).

${ }^{\circ}$ Copyright: the Author(s), 2020

Licensee PAGEPress, Italy

Research in Psychotherapy:

Psychopathology, Process and Outcome 2020; 23:202-210

doi:10.4081/ripppo.2020.487 cept to buy groceries or seek medical attention, and thus a ban on visits to other family and friends', some patients managed well enough. They went for walks around their home, some did extra cleaning of the house, some learned yoga and meditation and joined in Zoom classes, some made an effort to construct a daily routine for their lives, with time for online work and domestic life. Some of my patients did not find any real difference in their lives because they had always worked from home and lived an almost hermit type existence of social isolation. Some of my patients flourished under lockdown, enjoying the time spent at home with family. These patients viewed therapy as a process of self-reflection and a time to take a deep dive into the unconscious. Some of my patients did not manage so well. Most of these who did not cope well started prescription medication for either anxiety or depression, and some had physical symptoms associated with this, such as tension headaches or loss of interest in things that had previously excited them. These are the patients whose experiences are documented in this paper.

Anna ${ }^{1}$ is a 34 -years-old single, working woman living alone in a small suburban home in the city. She lives in a so-called middle-class area where most people are generally functioning well, have careers, cars, money in the bank, go on holidays, and enjoy going out to restaurants for meals with family and friends. Anna has access to

\footnotetext{
The name Anna and all other names of patients' are pseudonyms. Any other identifying data related to them have been changed so as to protect their identity.
} 
medical insurance and can pay for psychotherapy. For almost six months she had been exploring her anxiety and stress regarding her sense of not being good enough. Included in this exploration were the experiences of an intrusive, demanding, critical mother, and an inconsistently unavailable father.

In the previous five months, however, we, and my other patients, had unexpectedly shifted to the modality of online psychotherapy ${ }^{2}$ because of the lockdown. I call this new space the virtual therapy space because now we relate to each other through the screen. In a sense it is a relational virtuality. Because it was an unplanned shift for both of us, we discussed this shift at length and decided that without it there would be no therapy. The unplanned shift to online therapy changed many things in therapy, including the arrival of new anxieties not previously encountered before.

In addition to Anna, there is also Nevern, Bongani, Johan, and Molemo. These are my other patients. All are living under lockdown. They are linked by a common socio-economic status of middle-class, and work online with me from within a psychoanalytic framework. They are all employed but work online from home. Together with Anna, their collective (anxious) voices create a narrative of negotiating new anxieties and fears. In the shadow of COVID-19 pandemic, all these patients lives have substantially changed. While online psychotherapy is not new to the therapeutic community (Cipolletta, Frassoni, \& Faccio, 2018; Manfrida, Albertini, \& Eisenberg, 2017 ) and has been practiced for many years in various therapeutic modalities (although online psychoanalytic psychotherapy is rare) the experience of a global lockdown is new, and the experience of a global unplanned shift to online psychotherapy, while under the shadow of this lockdown, is new. In my mind, working therapeutically with these new experiences and new anxieties has become core to many analytic processes. The important focus lies in compassionately understanding our patients while we are also working and living under lockdown. The principle question is: What are these new experiences and new anxieties that my patients have to negotiate?

\section{What this paper is about}

This paper is an exploratory narrative description of the lived experiences of a number of my South African patients that collectively produce anxious voices from the unplanned shift to online therapy while living under the world's longest lockdown in the shadow of the COVID19 pandemic. To this end, this paper provides a thematic

\footnotetext{
Online psychotherapy, referred to as online therapy, is a psychotherapeutic intervention that makes use of the Internet and its various eplatforms, such as Skype, Zoom, MS Teams, WhatsApp, to connect mental health professionals registered and legally permitted to offer psychotherapy with their patients or clients.
}

description of some of the experiences that emerged from my work with them. It thus focuses on moments in therapy, which illustrate the impact of lockdown on their sense of self, and the emergence of new anxieties that shape the analytical material. The paper also details the experience of the unplanned shift to online therapy, rendering the therapeutic space to a virtual one, enacted on a flat screen.

As it is based on psychoanalytic therapy, the description of experiences places a value on the therapist's input into the process as well, thus centralizing the concept of intersubjectivity. In this regard, my own personal experiences and thoughts are seen to contribute to the analytic material that emerges.

The core contribution of this paper to the practice of psychoanalytic psychotherapy is that adds a voice to the growing number of experiences of other patients who are also living under lockdown in other parts of the world. Thus it seeks to build a broad picture of how patients are managing, or not, with the threat of COVID-19 pandemic. Without this kind of narrative documentation, the therapeutic community may not know the extent of the anxieties of living under lockdown in the shadow of the COVID-19 pandemic.

\section{A brief description of the world's longest lockdown}

At the time of writing, in early August 2020, South Africa is still in continuous lockdown, entering its fifth month, beginning $26^{\text {th }}$ March 2020. At this time, the country now ranks $5^{\text {th }}$ in the world in terms of the number of confirmed COVID-19 cases, which are close to 500,000 cases. There have been five levels of lockdown restrictions. Level Five, the strictest in terms of movement and freedoms, was implemented for five weeks from $26^{\text {th }}$ March 2020. During this five-week period, no one was allowed to leave home except to buy food or visit a doctor. Level Four, with a few more freedoms, such as a few essential businesses being opened, was implemented immediately afterwards for four weeks. After nine weeks of strict limitation on movement, lockdown was shifted to Level Three on $1^{\text {st }}$ June 2020. South Africa remains at Level Three.

Level Three allows for some greater freedoms of movement but many businesses remain closed, such as gyms, and the tourism industry. Unique to South Africa is a ban on alcohol and cigarettes for these past five months. At Level Three, all international borders are still closed, inter-city visits are still banned except for business purposes, schools are still shut, except for final years of primary school (12 years old) and secondary schools (17 years old), and many universities have now shifted to remote learning. The wearing of mask is still compulsorily. Effectively, most school children and university students remain at home after five months. The economy has 
shrunk by $7 \%$, with about six million job losses, and many businesses declaring bankruptcy. In a poor, developing African country like South Africa, with a population of 60 million, this economic slump is devastating, perhaps more damaging than the impact of the coronavirus crisis. There are fewer deaths thus far from COVID-19 than the annual flu deaths.

The most significant and continuous restriction for the past five months of lockdown, in terms of the psychological well-being of citizens, has been a ban on family visits.

\section{Living under lockdown}

As a result of the COVID-19 pandemic and the implementation of lockdown in late March 2020, all my therapy sessions shifted to online. After asking my patients which platform they preferred to use, I was skilled at Skype, WhatsApp, MS Teams, and Zoom. Below is a description of various psychological themes that emerged from moments in therapy.

\section{New anxieties about death and dying: The mask becomes the visible face of COVID-19}

The global COVID-19 pandemic, with its threat to life because there is no cure, and the enforced lockdown, gave rise to new anxieties for my patient, Bongani, a 30-yearsold man, married with three children. At the time of the unplanned shift to online therapy, he had been living with his wife in a small house in the city. Just before lockdown, the wife had left to visit her family in a neighboring province. In the first five weeks of lockdown, because no travel was permitted between provinces, he was without his wife and had to take care of the children as well as manage his work online. Our therapy had consisted of his lack of progress on his main project at work. He procrastinated to an extent of being threatened with dismissal from work. On further analysis, he discovered that he felt resentful of a successful father who always compared Bongani to his younger, more successful sister. Living with his children in the absence of a loving wife meant that therapy had moved away from his procrastination to his fear of not being able to see his wife for fear of dying from the COVID-19 disease. The main theme that emerged in therapy during lockdown was his new anxieties and fears of dying.

In one session he had been describing his fear of dying from the coronavirus. He had said that "it is a terrible way to die. You simply can't breathe anymore. You suffocate. I don't want to die like that". I asked him to explore a bit more the fear of dying. He said, "I have never thought about my own death before until this COVID-19 virus pandemic. Now I am consumed with it. When I leave the house, I sanitize my hands, when I return, I sanitize my hands. I also sanitize all the groceries. I am obsessed with cleaning. I am afraid of catching the virus and dying like that. Yes, I have never really had time for thinking about death, about my death. Why would I do that? I am too young to think about dying. I just cannot really fathom it that I might get infected and die. I know people in their 30 s that have died. They were young. They had no comorbidities".

While the fear of death from COVID-19 was central to some of my patients' experiences, I found that many did not explore it in much depth. It could be that it was too overwhelming or anxiety-provoking. Bongani however, did move to deeper levels of exploration during our sessions. What emerged for him was that he was fearful of death because it meant that he no longer existed, in fact, for him, the concept of non-existence is false because death is nothing: there is nothing so no concept of existence exists. He said he had his whole life ahead of him and to die so young would be to never have had the chance to self actuate or become the self he wanted to be. He said he had many goals to achieve. Death for him was conceptualized as "a thief in that it takes away what could be" thus it was approached as something terrifying. His fear of death made him aware of what he could lose, of what was precious. It gave him perspective on the finiteness of his life, and thus the limitations of time and what is possible in terms of self-individuation.

My own thoughts about death from COVID-19 are similar to Bongani's. I had not mentioned anything to him about my thoughts about death, and when he spoke of his fear of dying, it resonated deeply with me. The reason for not mentioning to him my own thoughts about death was that I wanted him to focus on, and share, his experiences, and not be drawn away from his process to become aware of my experiences. While sometimes I do share my experiences if I feel the self-disclosure will assist the client in some way, in this instance I intuitively felt the need to hold back my own experiences with death. In retrospect, I felt it was the right decision because he opened up more about his feelings. When he spoke about it, the fear I had of dying, together with his fear of dying, collectively mingled to produce a kind of dead third (Gerson, 2009). I found my own thoughts coagulating around memories of death and loss, as well as a near-death experience about two years ago. These moments of loss and confrontation with death were all an astonishingly powerful psychic event for me. Psychically, I had been processing thoughts of death and dying, and in the context of what Bongani was saying, I found that I was re-thinking not only on my own death, but the deep fear of dying which I thought I had 'processed well enough' to not be dogged by it now. My fear of death mirrored his fear of death. Death anxiety, however, is a common phenomenon (Frommer, 2016; Knight, 2019; Slavin, 2016).

Freud (1923) viewed death as difficult to think about and conceptualize because it is not experienced and, therefore, it remains at the level of theory or it is too abstract. As such, he said it is not a part of, or represented in, the 
unconscious. While Freud (1920) described the theory of the death instinct, this theory did not incorporate the psychic impact or significance of having to die. He thus gave death no psychic significance whatsoever. In this light, I am reminded of psychoanalyst Martin Frommer's (2016) inspired essay regarding death in psychoanalysis. He said that "despite profound changes that have taken place in psychoanalytic theory and practice over the last several decades, the human awareness of mortality continues to be treated as if it were not a defining psychic issue" ( $p$. 374). He noted that while modern psychoanalysis has become one of intersubjective dialogue in helping minds symbolize experiences, the relational turn has not yet fully considered the need of the solitary mind to be joined in confronting its own eventual demise. Moreover, a growing body of psychoanalytically-informed research provides new dialogue on the impact of the absence of death as a psychic issue, and thus the conscious awareness of death, and death anxiety, for both therapist and client in the process of therapy (Frommer, 2005, 2016; Hoffman, 2013; Knight, 2019; Piven, 2003; Razinsky, 2013; Slavin, 2011, 2013, 2016; Yalom, 2008).

Mushrooming out of this recent literature is the critique that in the past death anxiety was viewed not so much about death per se, as it was about other anxieties related to early or infantile fear of abandonment and separation, as well as early anxieties of castration and the unthinkable terror of annihilation (Piven, 2003).

So much about the anxiety of death was often positioned as anxieties about something other than death, such as psychic death or annihilation anxiety. Death anxiety is not the same as annihilation anxiety (Frommer, 2016). Annihilation anxiety is a more primitive response to a perceived threat or an actual early developmental trauma (Hoffman, 2013). As such, annihilation anxiety is the experience of dissolving or disintegration of the self's psychic structure, and an ensuing incipient dissociation and break down (Frommer, 2016). The experience of a dissolving self, which may be understood as an impending psychic death, is substantially different from "the total absence of experience - the nothingness of death" (Frommer, 2016: p. 378). In this regard, annihilation anxiety is about disintegration and falling apart, it is not, as with death anxiety, about the fear of non-existence. "Annihilation anxiety is about something more terrifying than nothingness and death: the experience of being present and witnessing the process of one's self shattering, and the ensuing dis-connection both to oneself and to others" (p. 378). In this context, the anxiety associated with one's own death may be, to some extent, the outcome of a failure to psychically comprehend what death implies - nothingness (Frommer, 2016), and as a result, this lack of representation of death is itself a primary source of anxiety (Razinsky, 2013). As therapists, death anxiety is something that needs to be spoken about. While existentialists have made reference of the anxiety of death, such anxiety becomes heightened in times of personal and collective distress and threat to life. Talking about death anxiety in therapy brings it into the process as a psychic experience to be explored and meaning found, whatever this meaning may look like.

When there is death-talk (Knight, 2019) in analysis like this between Bongani and me, and it is not "shut down by the therapist's unformulated experiences of loss" (Knight, 2019, p. 314) it shifts the intersubjective relationship towards an engagement of two minds unconsciously merging to form an analytic third (Ogden, 2004 add this in the references list) that is imbued with death and dying (Knight, 2019). In a sense, not only is it like a dead third mentioned above, but it is also a fearing and fearful third that would rather not feel such death anxiety. To this end, Bongani's experience of the fear of death and dying as well as his exploration of this experience of death anxiety, is an example of how this fear of death can be a subject of analysis. Bongani began to face the frustrating limitations of his young life as bounded by time. His fear brought an awareness of what he could lose - death is "a thief in that it takes away what could be". The impact of COVID-19 pandemic edged him towards a confrontation with death (Yalom, 2008) pulling me along too, and igniting for me old fears of dying. Perhaps what is terrifying is the way one dies from COVID-19. As Bongani said, "it is a terrible way to die".

With the advent of the COVID-19 pandemic, death surrounds us all. Linked to his death talk was his experience of wearing the mask in public spaces. He felt that the mask would protect him from contracting the virus. To him the mask was linked to fear of death and dying. He said that it was "a protective layer against the virus of COVID-19 that would seek to kill me". I asked him to talk a bit more about this experience and he related to me how the mask is like a condom preventing disease from coming into the body. He spoke about how he sanitizes everything, and feels obsessive and anxious all the time about having a clean mask. It seemed to me like the mask was a shield of sorts defending him.

While we may wear masks and sanitize hands, keep our distance, and stay home, for some patients the coronavirus crisis has ushered in a new level of anxiety about death and dying, a global, collective fear of contracting the virus and not being one of those who recovers. To this extent, while we experience the virus as an invisible threat to life, lying unseen on surfaces, but to my mind the virus is made visible in the display of the obligatory public mask. Of course at some level, the virus is too small to be seen, but we are reminded of the virus's presence by looking at other wearing the mask, or using the mask. Public spaces are now mask-spaces. The mask becomes the visible face of COVID-19.

As such, the mask is a social defensive maneuver to ward off death. In other words, it is a thin veil of fabric which promises protection from infection, and thus prom- 
ises to ring-fence death and keep us safe from dying. The mask is a transcultural symbol of an anxious global hope that by wearing it, death by this deadly virus can be defended off. Is this really possible? Bongani seemed to think so. The wearing of the public mask is the new social ticket that allows one to enter the new world order organized around the fight against the threat of death posed by the coronavirus. But it is also a thin veil of fabric that allows connection between people in public spaces, and is a desperate confidence that death will not enter the nose or mouth, and that contact with the other is not too dangerous.

\section{New anxieties about loss of contact with friends and family and the emergence of existential anxiety}

Nevern, a 24-years-old man was suffering from anxiety when we started therapy six months before lockdown. He had also experienced a painful break up with a longterm partner. Now we were into our second month of changing to online therapy as a result of lockdown. I asked him how he was coping with lockdown, he said, "my life is interrupted. All that I once did before lockdown, my meetings with family and friends, how I lived my life and socialized, no longer exists". In one session prior to lockdown, we had been exploring his anxiety about this break up. This led to his childhood memories of his parents' divorce, and how he felt abandoned by his mother when she moved away to begin a new relationship with another man. Nevern had always felt empty and alone when friends of family were not around. When lockdown began he found himself living alone and not allowed to visit friends or family. After almost 12 weeks of various internet meetings with friends, he found himself becoming increasingly anxious because he felt the internet contact was not enough. He wanted to be with them in the same space.

We explored this anxiety in a session one day. He said, "I feel dis-connected from my family, from being with them in the physical sense where I can touch and hug them. I feel that I need their company. I don't want to be alone. I cannot do this lockdown thing because it means I am not allowed to be with them". He also said, "I feel anxious about the loss of real contact with them because online contact feels unreal to me. It is like watching a TV screen, they are there on a screen but I feel they are not really with me. I feel totally alone. I go to bed at night and feel this anxiety about being alone. I am unsettled and want to be with my family again". I said, "It makes sense to me that you would want your family again in the real physical sense and not via a screen. I hear what you say about being anxious, alone and unsettled. This can't be easy for you. I wonder if you would like to talk more about your feelings because I get the sense that things are not okay for you at the moment". From my own experience, I could relate to wanting some physical contact with friends and family. I also had only been relating to my friends and family in the context of a virtual space. At one point I said, "Yes I really understand what you mean and I feel the same way as you". He replied to my statement that it was a relief to know that he was not alone in feeling this way.

In further exploration, he spoke about a new level of anxiety that he had not encountered before. It was essentially based on his aloneness and loneliness while living under lockdown. He also made the link to his early experiences as a child of feeling left alone by his mother. Living under lockdown, the impossibility of visiting family had heightened his sense of isolation. The anxiety he felt could be interpreted as the beginning of facing his past life without his mother and its links to his current world of isolation and aloneness. Stuck at home, unable to visit family, he felt this anxious loss and dis-connection.

$\mathrm{He}$ also began to feel a more pressing sense of aloneness in relation to his life, and he began to question the meaning of life. New anxieties emerged for him related to existential meaning and meaningless of life. He said, "since not being able to be with family and friends, my life seems to have no meaning in it. Everything seems to be a dreary repetition of the same. Without my friends, I feel lost. It is now months since I have seen family. Without them, life has lost its meaning. These thoughts about meaninglessness scare me. I feel anxious and wonder what is the meaning of my life". I replied, "I hear what you say about your experience of the dreariness of life, and the sense of meaninglessness and how it scares you. I wonder if you want to maybe share a bit more with me about this experience? I get the sense this is important to you".

It could be postulated that meaning for Nevern is linked to connection with others. He is sensitive to being alone because of his past history, and now without his friends, he is 'lost', and life is a 'dreary repetition of the same'. For almost five months he has had no physical contact with them. In my mind, he was becoming depressed.

In the shadow of rebuilding a broken society after WW11, Johan Tillich (1952) characterized that time as the age of anxiety. He wrote that this anxiety was about doubt and meaninglessness. He believed that such existential anxiety or the anxiety of meaninglessness was one of the primary living condition of being human, and was present in every moment. The notion of existential anxiety was proposed by well-known psychiatrist Viktor Frankl (1963), a survivor of the Holocaust. He wrote about the concept of the will to meaning, which was assumed to be a human motivation in everyone but could be frustrated. This frustration could lead to an existential vacuum. An existential vacuum is defined as a psychic state of disidentification from what was once a sense of identity or self, and when there are no apparent clearly-defined demands and expectations from the world, and individuals themselves are unsure of their role. The situation generates anxiety. 
As indicated, I am aware that the loss of contact with people was the very thing that gave Nevern a sense of meaning. Without his friends and family visits, without others that he felt connected to and with, he was faced with a sense of life as meaningless. The fabric of our therapeutic relationship thus transfigured in a flimsy veil of connection, and together with threat of internet dis-connection, our connection itself was always tenuous. My own counter-transference was that he that he was drowning in a sea of anxious isolation and meaninglessness, detached from an anchor of sustaining friends. Even online therapy (online contact with friends) was not good enough. But during online work, I felt I was someone who affixed him to something, perhaps to life itself. At one point, I said "I am worried about you and your feelings of anxiety as well as isolation and meaninglessness". As a result, our process involved me checking for suicidal risk and putting in place a safety net for this.

Psychoanalytic theory has not extensively addressed issues of existential anxiety. It is now becoming a bigger part of the analytic process (Frommer, 2005; Mitchell, 2002; Slavin, 2016). While such theory has always discussed the impact of object loss (Winnicott, 1971) on development, it has not yet (had to) to address both object loss together and existential anxiety. In the light of Nevern's experience, this could be re-framed as existential grief.

\section{New anxieties about current household relationships and the emergence of object loss}

Living under lockdown for 86 days meant that members of a household were not allowed to move out and live elsewhere. This was stressful for some patients who found themselves in relationships in the household that was intolerable and stressful even before lockdown. While most of my patients continued with online therapy after lockdown was imposed, I had a few new patients come to see me during lockdown. These new patients presented with these kinds of situations - relationship problems with members of the household. In my experience, relationship difficulties, exacerbated because of not being allowed to move out of the house, were common presenting problems during lockdown. The most common relational problem was marital, as opposed to parent-child conflict, with couples arguing and wanting to separate. It is in this context that my new patient, Molemo, made contact with me.

Molemo, a 50-years-old married woman and mother of two sons in their early ' 20 s, found herself in a stressful household situation with her husband. Both were professionals and had worked together on numerous projects prior to the outbreak of COVID-19. Before lockdown, Molemo had discovered that her husband had been having an affair. He promised to end it. She trusted him. During lockdown, she discovered that he had not stopped the affair, and had been sneaking out of the house pretending to go to the shops to buy the groceries. He was actually meeting his mistress. Molemo, confined together with her cheating husband, was overwhelmed with anger, and new anxieties about how to manage the living space.

After several sessions of working with her anger and sense of betrayal, the sessions became couples' therapy. These were mainly focused on trying to find ways to live together under lockdown but also ways to help Molemo make sense of what had happened. At one point they agreed to put up inside the house in the main corridor a sheet of plastic that divided the house in two. One side was for her and the adult children, and the other side was for him. The children could migrate across this plastic border but not the couple. With this plastic division, Molemo seemed to manage well. When we reverted back to individual therapy because the husband was no longer interested in therapy, she said, "while this plastic sheeting works well enough, it makes me feel sad about my marriage. I find myself walking about my side of the house wondering what he is up to. Mostly I wonder if he has been sneaking out again. I want to catch him doing it and call the police to arrest him". I commented that she wanted to punish him for what he had done to her. With a history of a childhood home broken by divorce, and an absent father, Molemo had felt present echoes of this past loss. We explored this past-present connection, and the dynamics of loss. At one moment in therapy, she said, "I am very anxious because while I have been angry at him, I am also stressed about the real possibility of living life alone once lockdown ends. I have never been alone. With this plastic sheet between us, between our lives, I feel anxious for my future without him". I replied that I understood her anxiety, that after all these years of marriage, it would seem anxiety-provoking to face life on her own. I gave an interpretation that her fear of being alone and without him somehow mirrored other kinds of losses and aloneness. She replied, "yes I think I am reminded of my past when I think of him leaving me. He is only staying with me now because he is not allowed to leave the house. When he does, I think I will be anxious about being alone". Her reference to anxieties about facing life after lockdown alone made sense to me. While not facing the prospect of being alone once lockdown ends, I did wonder how it would be to face the world alone. I replied to her that I understood her anxiety about being alone, and shared with her that I would also feel the same way if I found myself facing life after lockdown alone. This self-disclosure seemed to give her a sense of being understood as she said, "yes, I think you can understand how hard life is to live alone, how hard it will be for me".

Living under lockdown for some has resulted in the heightening of family conflict because of the forced confinement and close proximity to others. It is as if familial conflict is now 'pushed right up in your face' because living space is suddenly crowded. While sheets of flimsy plastic can be erected to divide living space, for some the inner psychic divisions and splits of what once was good, can bring about new anxieties about the stress of the selfas-alone. 
In terms of analytic theory, the capacity to be alone is a psychic achievement. Winnicott $(1951,1971)$ viewed transitional objects in infancy as assisting the infant to cope with separation and stranger anxiety caused by the awareness of dependence and separateness. In addition, his concept of holding (Winnicot, 1960) gave the infant a sense of not needing to respond to the external world for a while and be nestled in the psychic holding arms of the mother. Transitional objects and the experience of holding built a sense of being alone as tolerable and even comfortable. Without enough experiences of holding and use of transitional objects, the loss of the other becomes traumatic and fearful. Winnicott (1971) termed this the anxiety of object loss. Framing Molemo's experience into an anxiety of object loss, one can perhaps view her fears as deeply destabilizing, to an extent that she feels she will not cope, meaning that at the psychic level, such loss becomes a fear of loss of self in the absence of the other. This process is similar to Nevern's experience of object loss and his sense of existential angst. Perhaps the impact of living under lockdown for some patients ushers in unsymbolised trauma of loss of object, and thus deep levels of unmentalized anxiety not faced before. The impact of lockdown as an experience of loss can perhaps become a gateway experience to the unblocking of previously hidden and unknown psychic material.

\section{New anxieties about the unplanned shift to online therapy and the threat of internet dis-connection}

Shifting to online therapy, or to the new virtual therapy space, meant that things were different, new, and new anxieties emerged. For most of my continuing patients, this new virtual space was not ideal. When we previously met in my rooms for therapy before lockdown, there was, in hindsight, an unappreciated sense of continuity. We both knew we had an uninterrupted analytic hour. There was no threat of our conversation unexpectedly being disturbed mid-sentence. With the unplanned shift to online therapy in the shadow of lockdown, the delicate invisible threads of internet connection were always present, and as such, its capacity to suddenly cut us off, to dis-connect us from each other, and thus to stop us from relating to each other: it was a shared anxiety. Anna and I had experienced an internet dis-connection once before, and our session had abruptly ended. Now, all sessions were framed by this threat of dis-connection. Anna said, "I always feel anxious that I will be dis-connected from you". I was aware of my own anxieties about being dis-connected, and I wondered if maybe she was picking up on this. When we had our first experience of internet dis-connection, I was nervous that maybe we would not be able to resume therapy. The abrupt ending was for me like a door shutting, something was lost from what was being experienced.

What does this new anxiety of dis-connection mean for her, for our relationship? I asked her about her expe- rience of this threat of loss of connectivity. She replied that it made her feel "an inexplicable anxiety" because she felt we would not be able to re-connect again. Her new anxiety about the threat of internet dis-connection could be interpreted in different ways, one of which was that it triggered old wounds about her father. He was an inconsistent presence in her life. She felt she would rather not have had him about at all than have him in, what she termed, "bit and pieces", referring to his unpredictable comings and goings.

While our online therapy was unplanned, it brought about new analytic material that may or may not have emerged, such as the exploration of new anxieties about separation anxiety not just about her father but about our relationship. Because our relationship could be interrupted, and she recognized this painful and unwanted possibility, her anxiety about dis-connection and separation was heightened to a point where she would rather not have online therapy because it replicated her (father's) uncomfortable comings and goings. At one point she said, "maybe it is best we don't have therapy like this because I can't cope with the possibility of an internet connectivity issue". I invited her to explore this further with me to which she replied, "my anxieties about us being dis-connected is about my anxieties of having you and then not having you". I replied, "if I hear you correctly, the experience of dis-connection with me, and then when we do re-connect is like having me in bits and pieces, like you had with your father. It makes you feel insecure, and a way to handle this is for you to wonder if maybe it is better to not to have me at all".

What can be noted is that the unplanned shift to online therapy brought about new anxieties about the experience of the possibility of internet dis-connection, and what this evoked for Anna. While issues of separation and loss may have at some later stage been addressed in face-to-face therapy with her, the sudden move to online therapy, with its vulnerability to internet connectivity problems, gave rise to the sudden emergence of new anxieties of separation from me. In addition, the analytic third (Ogden, 2004 add this in the references list) that we formed together from our conscious and unconscious minds, evoked a shared anxiety about continuity, the much needed ongoing-ness of the process without threats of interruptions.

I am reminded of Winnicott's notion of environmental impingements from the external world onto the infant psyche during development. While good for growth, if premature, pulls the infant away from a state of going on being forcing reality in too soon. Linked to adult development, and to Anna's experience with me, the threat of disruption meant that her process now entailed a shift to new anxieties that shifted her away from the security of continuity. In the shadow of lockdown, the experience of the unplanned shift to online therapy summoned an experience of not only separation anxiety but of threats to her experience in therapy of going on being. 
As indicated, my work online with clients has changed. There is a new virtual medium and we relate to each other through a screen. I do the best I can in holding them, and providing a safe space for the exploration of experiences. I think it is successful most of the time because the clients tell me so and return to therapy each week. I notice, however, the change online when clients cry, or show sadness and become tearful. My experience of their sadness is different online. While I can support and empathize, I sometimes feel dis-connected because of the screen, and would have maybe passed a box of tissues to them as an act of caring. Now they take care of their tears and reach for their own tissues. Maybe this is therapeutic just as much as had I given them tissues, for now they take care of their tears, and I sit and watch this happen.

\section{New anxieties about missing body parts: Part-body-on-the-screen relating versus what-was-once-whole-body relating}

In the shadow of lockdown, perhaps one of the main changes to our therapeutic experience when we shifted to online therapy was the relationship to the missing body parts. In my rooms, we both could see each other's entire body. Online therapy meant relating to a screen and framed head and shoulders, which meant that the rest of the body was not seen. Johan, a 40-years-old man suffering from depression, said to me one day, "I can't see your whole body. I don't know what you are doing with your legs, or hands, and when you move forward in your chair, your head becomes larger. I am relating to you through a flat screen that frames your head and shoulders. Leaving me to guess what is going on with your other missing body parts". I replied, "what does this new experience of my missing body parts mean for you?" He replied, "I feel as if I am relating only to a speaking head. There is something missing now". I asked him, "how does it feel to be relating to only a 'speaking head'? What is missing for you?" After a long pause, he carefully said, "relating to a 'speaking head' means I am missing something that I once had. I once had the whole of you. The whole of you is missing. When I could see the whole of you, your whole body, I could figure out how you were feeling about me. So if I said something dreadful, I used to watch how it affected you by watching your body".

I thought about this remark, and said, "I find it interesting what you are saying about my body. If I hear you correctly, my whole body gives you a sense of how I could be feeling, or how I could be reacting to you. My whole body gives you clues, and not seeing my whole body takes away some of the clues, leaving your experience of me to be a speaking head".

Johan responded, "Yes exactly. This experience of online therapy is okay because I have a connection to you, but it also leaves me wondering what is going on with the rest of your body that I don't see". I waited a bit to see if he would say more. I wanted to give him time for he had a history of feeling that no one gave him time to speak his thoughts. After a while, he then said, "I find it hard to not know what is happening with the rest of your body". I commented, "not knowing is hard for you. Not knowing what is going on with my body means to you not knowing how I may feel about you. It is hard. I am a head without a full body attached. You are right, from your side I have missing body parts, and like you mentioned before, I am a speaking head".

Before lockdown and the unplanned shift to online therapy, Johan had been relating to my whole body. Now I was a detached head, with unseen body parts. His experience of me, of my body, had changed. My whole body was one a way of relating to me, a way for him to read me. My body was a signal, an open book in which he could figure me out, what I was feelings and experiencing, how I reacted to him, and thus, how my body showed him things. My body was a projective screen that indicated things to him about me. Now he was left guessing what was going on with my body parts that he could not see, that were missing to him.

Given this experience of Johan, with online therapy, the (online) other becomes a speaking head. I become a speaking head. My experience of part-body relating is similar to Johan's. I could not see his whole body. His whole body was somewhere 'there' just below the flat screen and framed head, but at the same time, it was fundamentally absent because it was unseen, and thus because it was absent. I too was relating to Johan as a body that had some parts missing from my view. Shifts in his body would have indicated to me something about shifts in his mood. The unseen body parts had a similar impact on me. I was missing some information.

Psychoanalytic the body has been important in development. From the breast and the psychic shift to a good breast or a bad breast, a good object to a bad object, to the mouth and anus, to the genitals, and fear of castration, and to the body of the other/third other in the Oedipal phase. The body is the object. Psychoanalytically speaking, partbody relating becomes a core experience during online therapy for both patient and therapist because it means that some bodily aspects of our relationship as a whole are inevitably missing. Some clues as to how we feel are now non-accessible and thus unavailable. Missing body parts can be equated with missing parts of our relationship. There are now gaps in our relating to each other because there are gaps in what is seen and unseen. In a way, what is happening is part-body-on-the-screen relating versus what was-once-whole-body relating. This reminds me of Klein's $(1957,1958)$ developmental theory of partbody relating versus whole body relating, corresponding her two developmental positions of the paranoid position and the depressive position. Drawing from Klein, a contemporary view suggested here is that the whole body of the mother provides the infant with a bodily experience, 
and thus a sense of self as body. Whole body relationship in analysis means that we both can see what is happening to the body. With no whole bodily experience of the other (me) Johan has an experience of me as partially dis-incarnate. In a sense, we both experience the other as partially dis-incarnate. In part-body-on-the-screen relating are we may be 'going backwards' and regressing to relating to each other from a more primitive ego level, a paranoid position level, where we feel anxious about attacks from the outside? Could the threat of attack be threats of disconnection, as described with Anna earlier?

\section{Final remarks}

This paper set out to present an exploratory narrative description of the therapeutic experiences of a number of my South African patients living under lockdown in the shadow of COVID-19. It focused on moments in therapy, which were shaped by the impact of living under lockdown. These experiences were all touched and tinged with new anxieties. In addition, new anxieties associated with the unplanned shift to online therapy, were also described.

These new experiences raise many issues about the human conditions of existence that are now shaped and formed under such extraordinary planetary circumstances. In the shadow of this coronavirus crisis, there seems to be a world-wide collective trauma as well as perhaps an equally global collective re-awakening to basic truths, however these are presented within different cultures and cosmologies, about the self and other, and about the intertwining of self to world, as well as about the need to (re)connect to what makes us human.

\section{References}

Cipolletta, S., Frassoni, E., \& Faccio, E. (2018). Construing a therapeutic relationship online: An analysis of videoconference sessions. Clinical Psychologist 22(2), 220-229.

Frankl, V. (1963). Man's search for meaning. Boston: Beacon Press.

Freud, S. (1920). Beyond the pleasure principle. Standard edition of the complete psychological works of Sigmund Freud (vol. 18, pp. 1-64). London, UK: Hogarth Press.

Freud, S. (1923). The ego and the id. Standard edition of the complete psychological works of Sigmund Freud, (vol. 19, 1-66). London, UK: Hogarth Press.

Frommer, M. S. (2005). Living in the liminal spaces of mortality. Psychoanalytic Dialogues, 15(4), 479-498. doi: $10.1080 / 10481881509348845$

Frommer, M. S. (2016). Death is nothing at all: on contemplating non-existence. A relational psychoanalytic engagement of the fear of death. Psychoanalytic Dialogues, 26(4), 373390. doi: 10.1080/10481885.2016.1190599
Gerson, S. (2009). When the third is dead: memory, mourning, and witnessing in the aftermath of the Holocaust. The International Journal of Psychoanalysis, 90(6), 1341-1357.

Hoffman, I. (2013). Response to Slavin: Considering the evolutionary and existential contexts of dialectical constructivism. Psychoanalytic Dialogues, 23(3), 315-323. doi: 10.1080/10481885.2013.794645

Klein, M. (1957). Envy and gratitude. In M. Klein (Ed.), Envy and gratitude (pp. 176-235). New York: Dell.

Klein. M. (1958). On the development of mental functioning. In M. Klein (Ed.), Envy and gratitude (pp. 236-246). New York: Dell.

Knight, Z. G. (2019). I am surrounded by death: death as a defining psychic issue within a relational psychoanalytic engagement and the impact of the therapist's relationship with death. Journal of Research in Psychotherapy: Psychopathology, Process and Outcome, 22(2), 308-316. doi:10.4081/ ripppo.2019.385

Manfrida, G., Albertini, V., \& Eisenberg, E. (2017). Connected: Recommendations and techniques in order to employ internet tools for the enhancement of online therapeutic relationships. Experiences from Italy. Contemporary Family Therapy, 39, 314-328. doi: 10.1007/s10591-017-9439-5

Mitchell, S. (2002). Can love last: The fate of romance over time. New York, NY: W.W. Norton.

Piven, J. (2003). Introduction. The Psychoanalytic Review, 90(4), 395-402. doi: 10.1521/prev.90.4.395.23918

Razinsky, L. (2013). Freud, psychoanalysis and death. London, UK: Cambridge University Press.

Slavin, M. O. (2011). Lullaby on the dark side: Existential anxiety, making meaning and the dialectic of self and other. In L. Aron \& A. Harris (Eds.), Relational psychoanalysis: Vol. 4: Expansion of theory (pp. 391-413). Hillsdale, NJ: The Analytic Press.

Slavin, M. O. (2013). Meaning, mortality, and the search for realness and reciprocity: An evolutionary/existential perspective on Hoffman's dialectical constructivism. Psychoanalytic Dialogues, 23(3), 296-314. doi: 10.1080/ 10481885.2013.794643

Slavin, M. O. (2016). Relational psychoanalysis and the tragic existential aspect of the human condition. Psychoanalytic Dialogues, 26(5), 537-548. doi: 10.1080/10481885.2016. 1214465

Tillich, P. (1952). The courage to be. New Haven, CT: Yale University Press.

Winnicott, D. (1951). Transitional objects and transitional phenomena. In D. Winnicott, Through pediatrics to psychoanalysis (pp. 229-242). New York, NY: Basic Books.

Winnicott, D. (1960). The theory of the parent-infant relationship. In D. Winnicott, The maturational processes and the facilitating environment (pp. 37-55). New York, NY: International Universities Press.

Winnicott, D. (1971). Playing and reality. London, UK: Routledge.

Yalom, I. (2008). Staring at the sun: Overcoming the terror of death. San Francisco, CA: Jossey-Bass. 